\title{
SEDIMENT SOURCE FOR MELT-WATER DEPOSITS
}

\author{
by \\ Fred Pessl Jr and Jan E. Frederick* \\ (U.S. Geological Survey, Puget Sound Earth Sciences Applications Project, University District \\ Building, Suite 125, 1107 N.E. 45th Street, Seattle, Washington 98105, U.S.A.)
}

ABSTRACT

A question is posed regarding the source of melt-water sediment. Does stagnant ice, functionally separated from active ice and gradually melting in place, contain enough rock debris to account for the volume of melt-water deposits known to exist in deglaciated areas, or does the volume of these deposits require a sediment source in close association with active ice from which the supply of rock debris is continually replenished?

Differing opinions on this question are implied in two contrasting models for deglaciation in the north-eastern United States. One, involving regional stagnation, assumes a sediment source in stagnant glacier ice; the other, involving stagnation-zone retreat, considers active ice the principal sediment source. This paper presents reported values of debris content in glacier ice and uses these values to calculate theoretical sediment volumes for a small drainage basin $\left(1300 \mathrm{~km}^{2}\right)$ in northeastern U.S.A.

A typical value for the amount of rock debris in temperate glacier ice is $25 \%$ (volume) debris content in a 400 mm-thick basal debrisrich zone. This value gives a calculated sediment volume of $0.13 \mathrm{~km}^{3}$, about $6 \%$ of the estirnated actual volume of melt-water sediment in the test basin. Comparison of calculated theoretical sediment volume with the estimated actual sediment volume in the basin indicates that stagnant ice is an inadequate sediment source, and that active ice, rather than stagnant ice, is probably the principal sediment source for melt-water deposits.

\section{INTRODUCTION}

In recent years there has been an increasing inclination on the part of glaciologists and glacial geologists to exchange ideas. Important productive aspects of such discussions are new perspectives, new analytical approaches, and new questions. The recent 0ttawa Conference in 1978 (Journal of Glaciology 1979) was a noteworthy example of this new dialogue, with attention focused on the glacier bed where complex physical and chemical mechanisms operate to determine erosional processes, transport modes, and depositional systems.

In the context of this interdisciplinary focus on glacial processes, we pose a question regarding the source of melt-water sediment: does stagnant ice, functionaliy separated from active ice and gradually melting in place. contain enough rock debris to account for the volume of melt-water deposits known to exist in deglaciated areas, or does the volume of these deposits require a sediment source in close association with active ice from which the supply of rock debris to melt-water streams is continually replenished?

In most melt-water systems envisioned by glacial geologists the bulk of the sediment is assumed to derive from rock debris that has been carried within or on the glacier. One such model, involving regional stagnation of a continental ice sheet, was proposed by Flint $(1929,1930)$ to explain the disappearance of the last ice sheet from parts of the north-eastern United States. This mociel required that debris concentration in the ice sheet or beneath it at the moment of stagnation was sufficient to account for the volume of late-Wisconsinan melt-water sediments that occur in some glaciated parts of the northeastern United States. An alternate view of late-glacial history in this region contends that: (1) deglaciation was characterized by the systenatic northward retreat of an active ice margin bordered by a narrow stagnani zone (Jahns 1941, Currier 1941, Schafer and Hartshorn 1965, Koteff 1974, Koteff and Pess 1, in press); (2) that stagnant ice contains relatively little rock debris; and (3) that active ice, acting as a conveyor belt, is necessary to supply significant volumes af rock debris to melt-water streams (Koteff 1974, Koteff and Pess1, in press).

An opportunity to examine the question of sediment source for melt-water deposits as one aspect of this controversy is presented by recent work in the Shetucket River basin, Connecticut (Fig.1). BTack (1977) has argued in favor of regional stagnation as the model for deglaciation of the Shetucket River basin. Part of his discussion is based on his interpretation that the relatively small volume of water-laid glacial sediment within this basin precludes a sediment source in active ice, thereby favoring regional stagnation wherein sediment is derived primarily from in situ wasting of dead ice. This paper focuses on the question of the melt-water sediment sources by presenting data on reported values of debris content in glacier ice and by using the Shetucket River basin in north-eastern U.S.A. as a test area to compare these reported 


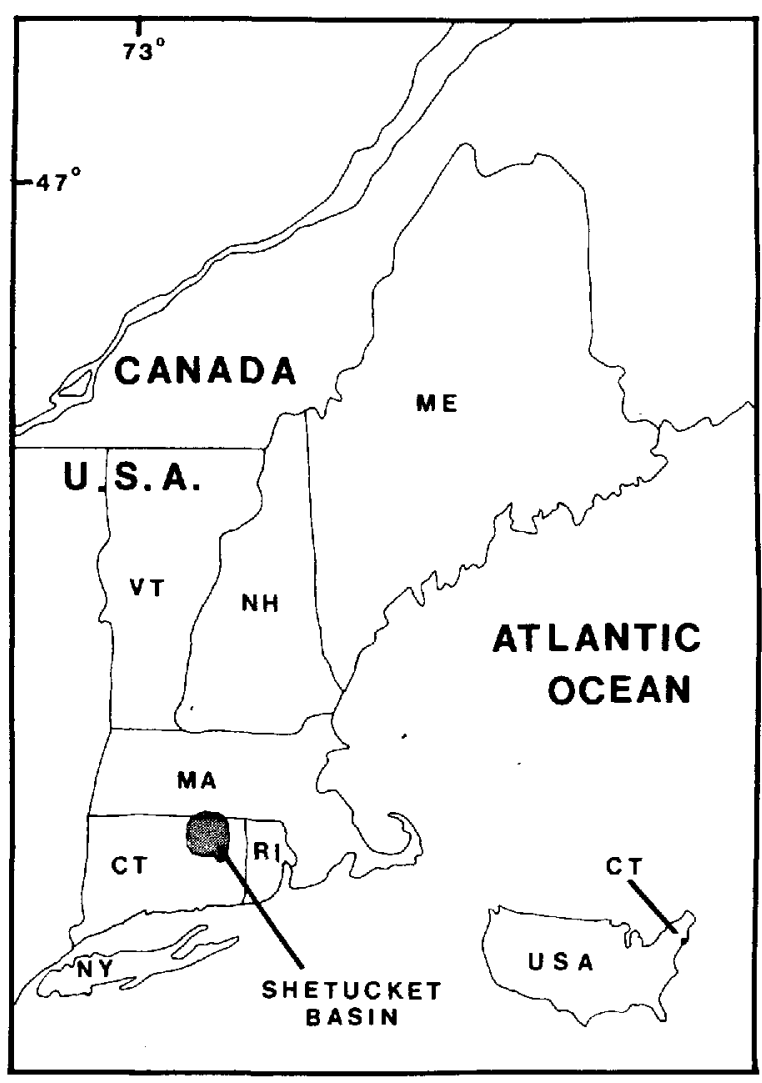

Fig.1. Map of north-eastern United States of America showing location of Shetucket River basin.

values with the volume of melt-water deposits estimated to occur within the basin.

\section{DEBRIS CONTENT IN GLACIAL ICE}

The location and, to some extent, the size of a glacier influence the relative contributions of supraglacial, englacial, and subglacial debris to the total debris load in a glacier. In an alpine environment where valley glaciers prevail, the steady supply of debris as rock fall from steep valley walls onto the surface of the ice is quite significant and can account for much of the sediment load. This sediment can either be carried on the surface of the glacier, be incorporated into the ice and carried englacially, or be washed away by melt-water streams on and adjacent to the ice. Subglacially-derived debris is relatively less significant in an alpine glacier. Debris derived subglacially in a larger ice sheet, however, is a major part of the total sediment load. As the thickness and areal extent of the ice mass increase, the ratio of surface area receiving debris (from nunataks and abutting valley walls) to the area contributing debris subglacially decreases. In this discussion, we assume a negligible contribution from supraglacial debris and concentrate on that sediment which is derived subglacially. Debris in the basal zone of a glacier is typically concentrated in bands ranging in thickness from a few centimeters to nearly $1 \mathrm{~m}$. The amount of sediment within the debris-rich bands varies considerabiy; however, the upper limit for significant debris concentrations most of ten quoted is between 40 and $55 \%$ by volume (Boulton $1970[\mathrm{a}], 1970[\mathrm{~b}], 1979$, Boulton and others 1974, Boulton and others 1979). These sediment-rich bands are typically separated by bands of relatively clean ice (less than $1 \%$ debris by volume (Boulton 1970[b])) ranging in thickness from a few centimeters to, in extreme cases, a few meters. The debris-rich bands are usually not continuous and have been observed in some glaciers to pinch out within a few meters. Many debris bands seem to be related to protuberances of bedrock into the glacier sole. This effect on debris concentration of streamlining from bedrock promontories has been discussed by Boulton and others (1979). They report that the presence of hummocks and intervening troughs in the bedrock floor causes debris bands to diverge from the up-glacier flanks of the hummocks and to concentrate in the troughs between hummocks, thus increasing the thickness of the debris-rich zone and the debris concentration in the troughs.

The thermal regime of a glacier affects the distribution and concentration of englacial debris. Traditionally, the thermal regime of a glacier has been classified as polar, subpolar, or temperate, depending upon how the temperature gradient varies throughout the ice sheet. As our understanding of glacier dynamics increases, this classification appears oversimplified, but a relationship does seem to exist between the thermal characteristics of a glacjer, the height of the englacial debris above the glacier sole, and the concentration of englacial debris.

Glaciers with a temperate thermal regime tend to transport debris almost exclusively within the lowermost meter (Boulton 1976, Boulton and others 1979). Colder glaciers (subpolar and polar) tend to carry the debris higher in the glacier, from a few meters to, in rare instances, tens of meters above the base (Gow and others 1979, Herron and Langway 1979). In both types, the debris is not continuous throughout the thickness of the debrisrich zone but is interlayered with bands of relatively clean ice. Observations from the Camp Century core, Greenland, where a basal temperature of $-13^{\circ} \mathrm{C}$ (Hansen and Langway 1966) suggests a polar regime, indicate $15.7 \mathrm{~m}$ of debris-rich basal ice with $0.24 \%$ debris by weight (Herron and Langway 1979), or approximately $0.1 \%$ by volume (Table I). The basal debris-rich zone in active ice of Spitsbergen glaciers is $0.4 \mathrm{~m}$ thick, and the maximum percentage of debris within the debris bands is $40 \%$ (Bouiton $1970[a]$ ). Unusually thick, debris-rich ice, such as the 30.5 to $67.0 \mathrm{~m}$ zone reported in the Barnes I ce Cap (Goldthwait 1951) and the 3 to $15 \mathrm{~m}$-thick basal zone with 4 to $25 \%$ debris by volume in the Matanuska Glacier (Lawson 1979), is restricted to ice-marginal areas. Rarely do these zones extend more than 400 to $500 \mathrm{~m}$ inward from the ice margin (Goldthwait 1951, Andrews 1972), and they are not representative of basal-debris concentration throughout the ice mass. Similarly, values of $40 \%$ debris concentration in a basal zone $2 \mathrm{~m}$ thick and 15 to $90 \%$ debris concentration in basal ice 3 to $4 \mathrm{~m}$ thick (Boulton 1970[a]) occur in the terminal zone. For the Barnes Ice Cap specifically, a more typical value for the thickness of debris-rich ice exclusive of the ice-marginal zone is about $300 \mathrm{~mm}$ (Goldthwait, oral communication 1978). At Byrd station, Antarctica, well inland from the ice margin, basal debris-rich ice is $4.82 \mathrm{~m}$ thick with $7 \%$ debris by volume (Gow and others 1979). Weertman (1961) and Boulton (1972 [a], 1972 [b]) have discussed the effect of variations in the thermal regime present within an ice sheet, and have suggested that glaciers are typically frozen to their beds at the ice margin (a polar characteristic), whereas at some distance toward the glacier interior there is water at the base (a temperate characteristic). Clayton 
and Moran (1974) have expanded on this idea in their "glacier-process form" model in which the thermal regine of an advancing continental ice sheet is divided into three zones: an outermost pro-glacial permafrost zone; a frozen-bed zone along the ice margin; and a thawed-bed zone in the interior of the ice sheet. During retreat, the frozen-bed zone is diminished or absent, and the thawed-bed zone extends outward toward the margin of the ice sheet, characteristic of a temperate-glacier thermal regime. Sugden (1978) has simulated the basal thermal regime of the Laurentide ice sheet at maximum steadystate conditions. In this model, three main zones delineate different processes acting at the glacier sole: warm-melting, warm-freezing, and cold-based. At the base of the center of the ice sheet there is a large zone of warm melting. A warm-freezing zone, where the most intensive erosion takes place, occurs outward from the center of the ice sheet, beyond the warm-melting zone. This warm-freezing zone is of variable lateral extent and grades into a broad cold-based zone where no significant deposition or erosion occurs. An outer warm-melting zone, characterized by deposition, occurs along the margin of the ice sheet.

\section{THE SHETUCKET BASIN}

The Shetucket River basin occupies a small (1 $300 \mathrm{~km}^{2}$ ) upland area in the north-eastern United States (Fig.1) that was last overridden by the Laurentide ice sheet 20 to $22 \mathrm{ka}$. Deglaciation of this area occurred approximately 14 to $15 \mathrm{ka}$. The basin has local topographic relief of 50 to $100 \mathrm{~m}$ and maximum topographic relief of $395 \mathrm{~m}$. It is bounded on the east and west by lowlands with major south-flowing streams and to the north by dissected highlands of moderate relief. At the southern basin boundary, the Shetucket River joins the Thames River flowing south to the Atlantic Ocean in Long Island Sound.

To determine the total volume of waterlaid glacial sediment derived from the wasting Laurentide ice sheet in the Shetucket basin, the area within the basin containing stratified drift was divided into 73 sub-basins. The sediment volume of each sub-basin was calculated by summation of a series of truncated cones, each defined by isopach contours showing thickness and distribution of water-saturated stratified drift (Thomas C E and others: 1967: plate B). The volume of each truncated cone was calculated according to the equation:

$$
V=\frac{1}{3} h\left(A_{1}+A_{2}+\sqrt{A_{1}+A_{2}}\right) \text {, }
$$

where $h$ is the thickness (contour interval), $A_{1}$ is the area of upper surface, and $A_{2}$ is the area of lower surface. The bottom section can be regarded as a cone, the volume of which is

$$
V=\frac{1}{3} h_{b}\left(A_{b}\right) \text {, }
$$

where $h_{b}$ is the thickness (half-contour interva 1), and $A_{b}$ is the lowermost isopach contour. The total volume of saturated stratified drift in the 73 sub-basins is $1.3 \mathrm{~km}^{3}$ which agrees with the estimate of $B$ lack (1977: 1336). However, an additional $0.7 \mathrm{~km}^{3}$ has been added to that total to account for the volume of stratified drift that occurs above the water table. This value is based on an estimated average thickness $(3 \mathrm{~m})$ of stratified drift above the water table as determined from 155 test holes in stratified drift within the basin from which data on depth to static water level are available (Thomas $M P$ and others 1967: 20-26), and on an estimated $18 \%$ of the

TABLE I. BASAL-DEBRIS CONTENT IN SELECTED GLACIERS, CALCULATED VOLUMES OF EQUIVALENT WATER-LAID SEDIMENT APPLIED TO THE SHETUCKET RIVER BASIN, AND PER CENT TOTAL SEDIMENT ESTIMATED WITHIN THE

\begin{tabular}{|c|c|c|c|c|c|}
\hline $\begin{array}{l}\text { Thickness of } \\
\text { basal zone } \\
\text { (m) }\end{array}$ & $\begin{array}{c}\text { Concentration } \\
\text { of debris } \\
\text { (\% by volume) }\end{array}$ & Reference & Location & $\begin{array}{l}\text { Calculated } \\
\text { sediment volume } \\
\text { applied to } \\
\text { Shetucket basin } \\
\left(\mathrm{km}^{3}\right)\end{array}$ & $\begin{array}{c}\text { Per cent } \\
\text { total sediment } \\
\text { estimated } \\
\text { within basin } \\
\left(2.0 \mathrm{~km}^{3}\right)\end{array}$ \\
\hline 0.40 & 40 & Boulton $1970[a]$ & $\begin{array}{l}\text { Nordenskiöldbreen, } \\
\text { Spitsbergen }\end{array}$ & 0.208 & 10 \\
\hline $0.05-1.0$ & - & Boulton 1971 & Alps, Norway, Iceland & - & - \\
\hline $0.1-0.2$ & $5-55$ & Boulton 1975 & & 0.143 & 7 \\
\hline $0.3-0.15$ & 50 & $\begin{array}{l}\text { Boulton and } \\
\text { others } 1974\end{array}$ & $\begin{array}{l}\text { Breidamerkurjökul1, } \\
\text { Iceland }\end{array}$ & 0.098 & 5 \\
\hline $0.1-16$ & - & $\begin{array}{l}\text { Engelhardt and } \\
\text { others } 1978\end{array}$ & $\begin{array}{l}\text { Blue Glacier, } \\
\text { Washington, USA }\end{array}$ & - & - \\
\hline 15.7 & 0.1 & $\begin{array}{l}\text { Herron and } \\
\text { Langway } 1979\end{array}$ & Greenland ice sheet & 0.020 & 1 \\
\hline 4.8 & 7 & $\begin{array}{l}\text { Gow and others } \\
1979\end{array}$ & Antarctic ice sheet & 0.44 & 22 \\
\hline 1.5 & - & $\begin{array}{l}\text { Wold and Ostrem } \\
1979\end{array}$ & Bondhusbreen, Norway & - & - \\
\hline $0.05-0.2$ & $8-10$ & Boulton 1979 & $\begin{array}{l}\text { Breidamerkurjökul1, } \\
\text { Iceland }\end{array}$ & 0.026 & 1 \\
\hline 2.0 & - & Boulton 1979 & $\begin{array}{l}\text { Wright Lower Glacier, } \\
\text { Antarctica }\end{array}$ & - & - \\
\hline $0.02-0.04$ & 43 & $\begin{array}{l}\text { Boulton and } \\
\text { others } 1979\end{array}$ & $\begin{array}{l}\text { Glacier d'Argentière, } \\
\text { France }\end{array}$ & 0.028 & 1 \\
\hline
\end{tabular}
BASIN 
total basin area underlain by stratified drift (Thomas C E and others 1967: 53). Total volume of stratified drift in the Shetucket basin is, therefore, $2.0 \mathrm{~km}^{3}$.

The water-laid glacial sediments in the Shetucket basin are late-Wisconsinan recessional deposits (Black 1977) and, as such, were most probably associated with a temperate-glacier thermal regime (Clayton and Moran 1974). The location of the basin also occurs in the outer warm-melting zone of Sugden (1978: fig.9). Using typical values for the amount of basal debris in temperate ice, i.e. about $25 \%$ debris in $400 \mathrm{~mm}$-thick basal debris-rich ice, we calculate that the volume of sediment available from a wasting ice mass occupying the Shetucket basin would be $0.13 \mathrm{~km}^{3}$, or only about $6 \%$ of the total volume estimated to have been deposited there.

The inadequacy of debris-rich, stagnant basal ice as the principal source of the Shetucket-basin melt-water sediment is also indicated by data from specific glaciers. Calculations of available sediment volume based on reported values of thickness and debris concentration in debris-rich basa 7 ice and the per cent of total sediment in the basin that is accounted for by these calculations are given in Table I. When extreme values of debris concentrations are used they account for only $22 \%$ of the total melt-water sediment present within the basin. In an attempt to consider an extrerne case of available sedinent from the ice mass, an ice-marginal zone, $2 \mathrm{~km}$ wide, was assurned to have been present in the basin. This increased the per cent of the total melt-water sediment accounted for to $34 \%$ (Table II). Because these values are significantly less than the volume of sediment estimated to be present in the basin, stagnant ice was probably not the principal sediment source. Furthermore, the estimated sediment volume in the Shetucket bas in is probabiy a minimum value. The estimate does not include debris deposited as melt-out till during ice recession, nor does it account for that portion of fine-grained sediment which doubtless was transported beyond the basin boundary as suspended load. Any such additions to the estimated total sediment volume in the Shetucket basin further weaken the argument for stagnant ice as the source of water-laid glacial sediment.

\section{DISCUSSION}

We recognize that, in addition to the contribution of rock debris from the basal zone of a continental glacier, supraglacial debris also contributes additional sediment to the melt-water drainage system. However, except for basal debris that becomes supraglacial in the terminal zone (due to upward-directed transport in active ice and to surface melting), the percentage of total sediment originated as supraglacial debris on a continental ice sheet is probably very small. This is especially so for an ice sheet dissipating in a region of low-to-moderate topographic relief such as the shetucket basin where steep, confining bedrockvalley walls and nunatak-forming promontories are not common. However, additional mechanisms, such as fluvial reworking of older glacial deposits and slope processes near the wasting ice sheet may also contribute sediment to the melt-water system. Goldthwait (personal communication 1980) reports that fluvial reworking of pre-existing glacial sediments is a major contributor of sediment to outwash forming today in front of stagnant ice in at least one basin in Alaska. This process may account for a portion of the late-glacial meltwater sediment in the Shetucket River basin. Whether or not it was a significant sediment source is difficult to ascertain. But the primary sediment source of such reworked material is still likely to have been active ice.

Available data on the amount of debris entrained within an ice sheet are sparse, particularly with regard to processes of meltwater sedimentation, and further research dealing with the volume and distribution of entrained glacial debris is most desirable. Debris distribution and debris concentration within an ice sheet appear to be highly variable. As previously noted, bed roughness probably is an important influence on the distribution and concentration of glacially transported debris (Boulton 1979, Boulton and others 1979). In addition, clean ice interlayered with sediment-rich bands and anomalously high debris concentrations in ice-marginal zones, as compared to more regionally representative debris concentrations, further complicate a realistic assessment of the volume of glacially transported sediment available to melt-water

TABLE II. BASAL-DEBRIS CONTENT IN ICE-MARGINAL ZONES OF SELECTED GLACIERS AND PER CENT TOTAL SEDIMENT ESTIMATED WITHIN SHETUCKET RIVER BASIN

$\begin{array}{cc}\text { Thickness of } & \text { Concentration } \\ \text { basal zone } & \text { of debris } \\ (\mathrm{m}) & (\% \text { volume })\end{array}$

(m)
Reference

Location
Per cent

total sediment estimated within basin $\left(2.0 \mathrm{~km}^{3}\right)$

$\begin{array}{ccc}0.5 & 30 & \text { Boulton 1970[a] } \\ 2 & 40 & \text { Boulton 1970[a] } \\ 3-4 & 15-90 & \text { Boulton 1970[b] } \\ 3-15 & 3-25 & \text { Lawson 1979 }\end{array}$

\section{Nordenskiöldbreen, Spitsbergen}

\section{Sørbreen}

Spitsbergen

Makarovbreen, Spitsbergen

Matanuska Glacier, Alaska 
drainage systems. However, presently available data, applied to the Shetucket basin, tend to support the interpretation that active ice, rather than stagnant ice, is the principle sediment source for melt-water deposits.

\section{REFERENCES}

Andrews J T 1972 Englacial debris in glaciers. Joumal of Glaciology 11(61): 155

Black R F 1977 Regional stagnation of ice in northeastern Connecticut: an alternative model of deglaciation of part of New England. Geological Society of America Buzletin 88(9): 1331-1336

Boulton G S 1970[a] On the deposition of subglacial and melt-out tills at the margins of certain Svalbard glaciers. Joumat of Glaciology 9(56): 231-245

Boulton GS 1970[b] On the origin and transport of englacial debris in Svalbard glaciers. Joumal of Glaciology 9(56): 213-229

Boulton G S 1971 Englacial debris in glaciers: reply to the corments of $\mathrm{Dr} \mathrm{J}$. T. Andrews. Journal of Glaciology 10(60): 410-411

Boulton G S 1972[a] Englacial debris in glaciers: reply to the comments of Dr J. T. Andrews. Journal of Gzaciology 11(61): $155-156$

Boulton G S 1972[b] The role of thermal régime in glacial sedimentation. In Price $\mathrm{R} \mathrm{J}$ and Sugden D E (eds) Polar geomorphology. London, Institute of British Geographers: 1-19 (Institute of British Geographers Special Publication 4

Boulton G S 1975 Processes and patterns of subglacial sedimentation: a theoretical approach. In Wright $\mathrm{HE} \mathrm{Jr}$ and Moseley $\mathrm{F}$ (eds) Ice ages: ancient and modern. iverpool, Seel House Press: 7-42

Boulton G S 1976 A genetic classification of tills and criteria for distinguishing tills of different origin. Geografia 12: 65-80

Boulton G S 1979 Processes of glacial erosion on different substrata. Journal of Glaciology 23(89): 15-38

Boulton G S, Dent D L, Morris E M 1974 Subglacial shearing and crushing and the role of water pressures in tills from south-east Iceland Geografiska Annaler Ser A 56A $(3-4): \quad 135-145$

Boulton G S, Morris E M, Armstrong A A, Thomas A 1979 Direct measurement of stress at the base of a glacier. Joumal of Glaciology $22(86): 3-24$

Clayton L, Moran S R 1974 A glacial processform model. In Coates DR (ed) Glacial geomorphology. Binghamton, NY, State University of New York: 89-119

Currier LW 1941 Disappearance of the last ice sheet in Massachusetts by stagnation zone retreat. Geological Society of America Buizetin 52 (12 Pt 2): 1895

EngeThardt H R, Harrison W D, Kamb W B 1978 Basal sliding and conditions at the glacier bed as revealed by bore-hole photography. Journal of Glaciology $20(84)$ 469-508

Flint R F 1929 The stagnation and dissipation of the last ice sheet. Geographical Review 19(2): 256-289

Flint R F 1930 The glacial geology of Connecticut. Connecticut State Geological and Natural History Survey Bulletin 47

Goldthwait R P 1951 Development of end moraines in east-central Baffin Island. Joumal of Geology 59(6): 567-577
Gow A J, Epstein S, Sheehy W 1979 on the origin of stratified debris in ice cores from the bottom of the Antarctic ice sheet. Journal of Glaciology 23(89): 185-192

Hansen B L, Langway C C Jr 1966 Deep core dri1ling in ice and core analysis at Camp Century, Green1and, 1961-1966. Antaretic Joumal of the United States 1(5): 207208

Herron S, Langway C C Jr 1979 The debris-laden ice at the bottom of the Greenland ice sheet. Journal of Glaciology 23(89): 193207

Jahns R H 1941 Outwash chronology in northeastern Massachusetts (abstract). Geological Society of America Bulletin 1(5): 207-208

Journal of Glaciology 1979 Symposium on glacier beds: the ice-rock interface. Ottawa, 15-19 August 1978. Journal of Glaciology $23(89)$

Koteff C 1974 The morphologic sequence concept and deglaciation of southern New England. In Coates D R (ed) Glacial geomorphology. Binghamton, NY, State University of New York: $121-144$

Koteff $\mathrm{C}$, Pess $7 \mathrm{~F}$ Jr In press. Systematic ice retreat in New England. U.S. Geological Survey Professional Paper 1179

Lawson DE 1979 Sedimentological analysis of the western terminus region of the Matanuska Glacier, Alaska. CRREL Report 79-9

Schafer J P, Hartshorn J H 1965 The Quaternary of New England. In Wright $H E$ Jr and Frey DG (eds) The Quatermary of the United States. Princeton, NJ, Princeton University Press: 113-128

Sugden D E 1978 Glacial erosion by the Laurentide ice sheet. Joumal of Glaciology 20(83): $367-391$

Thomas C E Jr, Bednar G A, Thomas M P, Wilson WE 1967 Hydrogeologic data for the Shetucket River basin, Connecticut. Connecticut water Resources Bulletin 12

Thomas M P, Bednar G A, Thomas C E, Jr, Wilson WE 1967 Water resources inventory of Connecticut. Pt 2. Shetucket River basin. Connecticut Water Resources Bulzetin 11

Weertman J 1961 Mechanism for the formation of inner moraines found near the edge of cold ice caps and ice sheets. Journal of Glaciology 3(30): 965-978

Wold B, Astrem G 1979 Subglacial constructions and investigations at Bondhusbreen, Norway. Journal of Glaciology 23(89): $363-379$ 